\title{
Purification and characterization of a novel neutral and heat-tolerant phytase from a newly isolated strain Bacillus nealsonii ZJ0702
}

Ping Yu* and Yirun Chen

\begin{abstract}
Background: Phytic acid and phytates can interact with biomolecules, such as proteins and carbohydrates, and are anti-nutritional factors found in food and feed. Therefore, it is necessary to remove these compounds in food and feed processing. Phytase can hydrolyze phytic acid and phytates to release a series of lower phosphate esters of myoinositol and orthophosphate. Thus, the purification and characterization of novel phytases that can be used in food and feed processing is of particular interest to the food and feed industries.

Results: A novel neutral and heat-tolerant phytase from a newly isolated strain Bacillus nealsonii ZJ0702 was purified to homogeneity with a yield of $5.7 \%$ and a purification fold of 44 . The molecular weight of the purified phytase obtained by SDS-PAGE was $43 \mathrm{kDa}$. The homology analysis based on N-terminal amino acid and DNA sequencing indicated that the purified phytase was different from other known phytases. The optimal thermal and $\mathrm{pH}$ activity of the phytase was observed at $55^{\circ} \mathrm{C}$ and 7.5 , respectively. Seventy-three percent of the original activity of the phytase was maintained following incubation at $90^{\circ} \mathrm{C}$ for $10 \mathrm{~min}$. The phytase was stable within a pH range of $6.0-8.0$ and showed high substrate specificity for sodium phytate. $\mathrm{Cu}^{2+}, \mathrm{Co}^{2+}, \mathrm{Zn}^{2+}, \mathrm{Mn}^{2+}, \mathrm{Ba}^{2+}$ and $\mathrm{Ni}^{2+}$ ions were found to inhibit the activity of the phytase.

Conclusions: A novel phytase purified from B. nealsonii ZJ0702 was identified. The phytase was found to be thermally stable over a wide temperature range at neutral $\mathrm{pH}$. These properties suggest that this phytase is a suitable alternative to fungal phytases for the hydrolysis of phytic acid and phytates in food and feed processing industries.
\end{abstract}

Keywords: Phytase, Purification and characterization, Heat-tolerant, Homology analysis, Bacillus nealsonii

\section{Background}

Phytic acid and phytates exist widely in edible legumes, cereals, oil seeds, pollens and nuts, and account for about $1-5 \%$ of the dry weight of plant seeds $[1,2]$. The presence of phytic acid and phytates in plant food and feed has been well documented [3-6]. They are a primary source of inositol and an important storage form of phosphorus in plant seeds that are often used as animal feed ingredients [7-9]. Because of their ability to interact with biomolecules, such as proteins and carbohydrates, they can act as anti-nutritional factors in several ways: (i) chelating cations, such as $\mathrm{Ca}^{2+}, \mathrm{Mg}^{2+}, \mathrm{Fe}^{2+}$ and $\mathrm{Zn}^{2+}$, to form insoluble

\footnotetext{
* Correspondence: yup9202@gmail.com

College of Food Science and Biotechnology, Zhejiang Gongshang University, 149 Jiaogong Road, Hangzhou 310035, Zhejiang Province, PR China
}

metal phytate complexes under gastrointestinal $\mathrm{pH}$ conditions; (ii) reducing the digestibility of protein, starch and lipids; and (iii) inhibiting the activity of enzymes, including amylase, trypsin, acidic phosphatase and tyrosinase [2,10-15]. Thus, it is necessary to remove phytic acid and phytates in food and feed processing to avoid the abovementioned problems.

Phytase (myoinositol hexakisphosphate phosphohydrolases EC3.1.3.8) cleaves phosphor- monoester bonds in phytic acid and phytates. This results in the sequential release of a series of lower phosphate esters of myoinositol and orthophosphate. Therefore, phytase has gained rapid acceptance as an animal feed or a food additive worldwide [16]. In addition, phytase has important applications in ameliorating human nutrition [17-19], as well as in some other areas, including aquaculture [20]. Thus, it is highly desirable to reduce the

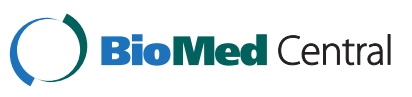

(C) 2013 Yu and Chen; licensee BioMed Central Ltd. This is an Open Access article distributed under the terms of the Creative Commons Attribution License (http://creativecommons.org/licenses/by/2.0), which permits unrestricted use, distribution, and reproduction in any medium, provided the original work is properly cited. 
content of phytic acid and phytates in food and feed processing by the hydrolysis of phytase.

A wide variety of phytases have been isolated from different organisms [21-31]. However, the focus has been on fungus-derived phytases that are active at low $\mathrm{pH}$ values and show low thermal stability [31-34]. Moreover, although the addition of phytase is widely used to improve the release of plant phosphorus in poultry and swine, the use of phytase in feed for aquatic species has not been developed [35]. Some aquaculture species are agastric and their digestive system $\mathrm{pH}$ is neutral. Thus, fungus-derived acidic phytases are of limited use to these species because these phytases show low activity at neutral $\mathrm{pH}$. Bacterial phytases are an important alternative to fungal ones because of their high thermal stability, phytate substrate specificity, wide $\mathrm{pH}$ profile and proteolysis resistance $[33,36,37]$. Therefore, the purification and characterization of novel phytases with high thermal stability and activity at neutral $\mathrm{pH}$ from bacteria is of particular interest for future industrial applications in food and feed processing.

In the present study, a novel neutral and heat-tolerant phytase from a newly isolated strain Bacillus nealsonii ZJ0702 from the soil was sequentially purified to homogeneity by ammonium sulfate precipitation, DEAE-sepharose Fast Flow column chromatography and Sephadex G-100 size-exclusion chromatography. The enzymatic properties of the purified phytase were investigated in detail.

\section{Results}

\section{Purification of the phytase from B. nealsonii ZJ0702}

The supernatant obtained by centrifugation of the culture broth at $12,000 \mathrm{rpm}$ for $20 \mathrm{~min}$ was used as the enzyme source. The purification of the phytase was sequentially performed by $\left(\mathrm{NH}_{4}\right)_{2} \mathrm{SO}_{4}$ precipitation, DEAE-sepharose anion-exchange column chromatography and Sephadex G-100 size-exclusion column chromatography. The purification results are presented in Figure 1 and Table 1. After $\left(\mathrm{NH}_{4}\right)_{2} \mathrm{SO}_{4}$ precipitation, $76 \%$ of the total protein was removed. The residual protein was subject to DEAE-sepharose anion-exchange column chromatography (Figure 1a), and the protein containing the activity of phytase was collected and pooled, giving $6 \%$ of the total protein. The protein was subject to further purification by Sephadex G-100 size-exclusion chromatography. Here, fractions 2-8 showed the highest phytase activity (Figure 1b). These fractions were collected and pooled, giving $1 \%$ of the total protein. The purification folds of phytase from the above three purification steps were 2 , 10 and 44, respectively. Corresponding recovery rates of the total activity of phytase were 49,6 and $5.7 \%$, respectively (Table 1). The SDS-PAGE analysis of the protein samples from the above three purification steps is shown in Figure 1c. Only a single protein band with an estimated molecular weight of $43 \mathrm{kDa}$ was present following the Sephadex G-100 size-exclusion chromatography step. This result indicates that the obtained phytase is electrophoretically pure and can be used for the analysis of enzymatic properties.

\section{Homology analysis of the phytase}

The homology tree of phytase based on the DNA sequence is presented in Figure 2. A very low sequence homology was found between the DNA sequence of the phytase from B. nealsonii ZJ0702 and phytases from selected microorganisms. The determined $\mathrm{N}$-terminal amino acid sequence of the purified phytase from B. nealsonii ZJ0702 is: MGAIDTCPNKYSTIRRVLIMN KKTQMIHGGH. A similarity comparison was also carried out between this protein sequence and the corresponding regions of other known phytases; however, no similarity was found. These results strongly suggest that the phytase from B. nealsonii ZJ0702 is different from other known phytases (Figure 2).

\section{Enzymatic properties of the purified phytase}

Enzymatic properties of the purified phytase are shown in Figure 3. The activity of the phytase increased when the temperature was increased from 20 to $50^{\circ} \mathrm{C}$, and reached a maximal value at $55^{\circ} \mathrm{C}$. Thereafter, it decreased rapidly as the temperature increased beyond $55^{\circ} \mathrm{C}$. This shows that the optimal temperature of the purified phytase is $55^{\circ} \mathrm{C}$ (Figure 3a). The activity of the phytase varied as a function of the $\mathrm{pH}$. The highest activity of the phytase was observed at pH7.5 (Figure 3b). For the phytase from B. nealsonii ZJ0702, strong thermal stability was observed at 37 and $55^{\circ} \mathrm{C}$. The activity of the phytase showed negligible change when incubated at either of these temperatures for $30 \mathrm{~min}$. The residual activities of the phytase were 75,62 and $41 \%$ when the protein was incubated at $80^{\circ} \mathrm{C}$ for 10,20 and $30 \mathrm{~min}$. The residual activities of the phytase at $90^{\circ} \mathrm{C}$ were 73, 51 and $21 \%$ when the protein was incubated for 10,20 and $30 \mathrm{~min}$, respectively (Figure $3 \mathrm{c}$ ). A high $\mathrm{pH}$ stability of the phytase was observed when it was incubated at $\mathrm{pH} 7.0$ and 8.0. At pH4.0, the activity of the phytase decreased dramatically as the incubation time increased, and only $1 \%$ of the original activity of the phytase remained after incubation at $\mathrm{pH} 4.0$ for $30 \mathrm{~min}$ (Figure 3d).

The effect of different metal ions on the activity of the purified phytase (Table 2) indicated that $\mathrm{Ca}^{2+}$ at $1 \mathrm{mM}$ and $5 \mathrm{mM}$ did not alter its activity. In addition, the activity of the purified phytase was not altered when $1 \mathrm{mMMg}^{2+}$ was added. However, the activity decreased by $38 \%$ when the concentration of $\mathrm{Mg}^{2+}$ increased to $5 \mathrm{mM} . \mathrm{Cu}^{2+}, \mathrm{Co}^{2+}$, $\mathrm{Zn}^{2+}, \mathrm{Ba}^{2+}, \mathrm{Mn}^{2+}$ and $\mathrm{Ni}^{2+}$ at $1 \mathrm{mM}$ and $5 \mathrm{mM}$ were found to inhibit the activity of phytase significantly. The relative hydrolytic rate of different phosphorylated compounds showed that the purified phytase exhibited very narrow substrate specificity (Table 3 ). The phytase showed high 


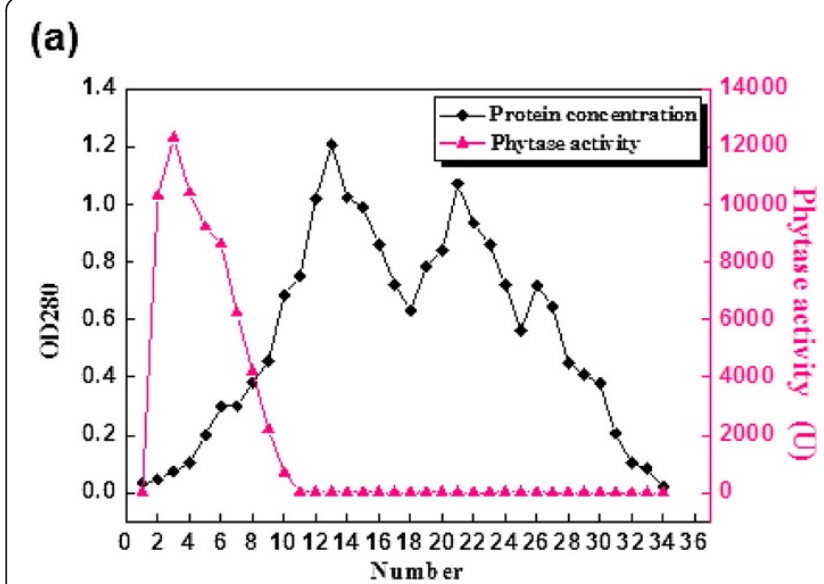

(C)

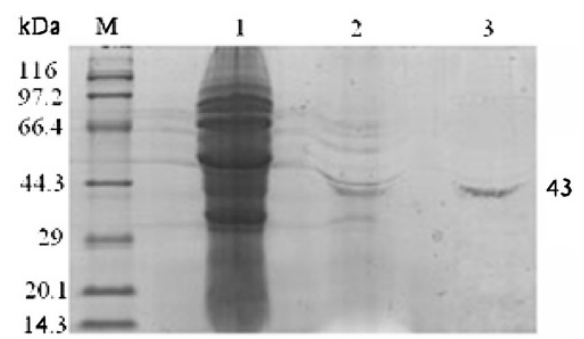

(b)

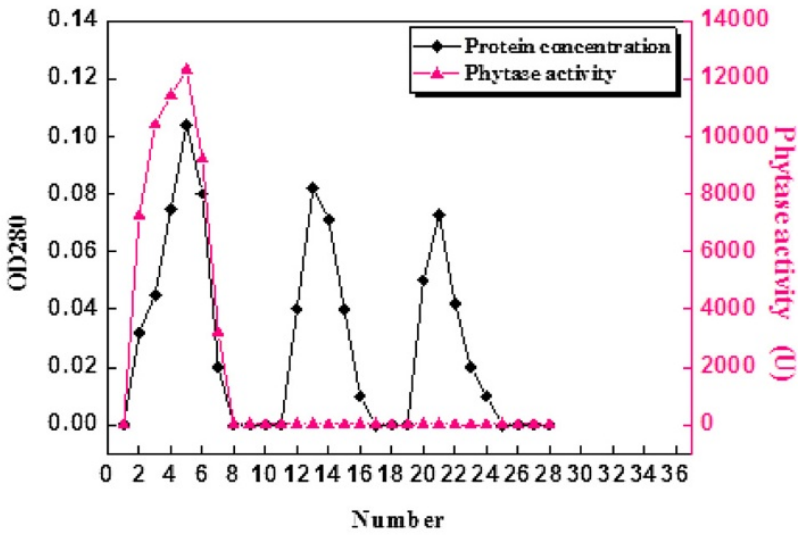

Figure 1 Elution curves of the phytase from B. nealsonii ZJ0702 and the SDS-PAGE analysis. (a) The elution curve of the DEAE-sepharose anion-exchange column chromatography purification step of the sample. (b) The elution curve of the Sephadex G-100 size-exclusion chromatography purification step of the sample. (c) The SDS-PAGE analysis of the phytase. M: protein molecular weight markers; lane 1: the sample from the crude extract; lane 2: the sample after DEAE-sepharose anion-exchange column chromatography; lane 3: the sample after Sephadex G-100 size-exclusion chromatography.

activity only towards the substrate sodium phytate. No phytase activity was detected when other phosphorylated substrates were used.

\section{Discussion}

In this study, a neutral and heat-tolerate phytase from B. nealsonii ZJ0702 was purified to homogeneity, and the homology analysis based on N-terminal amino acid sequencing and DNA sequencing revealed that the phytase is novel. This enzyme display the optimal activity at $55^{\circ} \mathrm{C}$, which is similar to that of other known phytases from particular microorganisms, such as Mucor hiemalis $\left(55^{\circ} \mathrm{C}\right)$,

Table 1 Purification results of the phytase from a newly isolated strain B. nealsonii ZJ0702

\begin{tabular}{llllll}
\hline Purification steps & $\begin{array}{l}\text { Total } \\
\text { protein } \\
(\mathbf{m g})\end{array}$ & $\begin{array}{l}\text { Total } \\
\text { activity } \\
(\mathbf{U})\end{array}$ & $\begin{array}{l}\text { Specific } \\
\text { activity } \\
(\mathbf{U} / \mathbf{m g})\end{array}$ & $\begin{array}{l}\text { Purification } \\
\text { fold }\end{array}$ & Yield \\
\hline Culture broth & 101.7 & 8760001 & 8611 & 1 & $\mathbf{( \% )}$ \\
\hline $\begin{array}{l}\left.\mathrm{NH}_{4}\right)_{2} \mathrm{SO}_{4} \text { precipitation } \\
\text { DEAE-sepharose }\end{array}$ & 24.7 & 4300001 & 17430 & 2 & 100 \\
$\begin{array}{l}\text { Fast Flow } \\
\text { Sephadex G-100 }\end{array}$ & 1 & 526240 & 87120 & 10 & 69 \\
\hline
\end{tabular}

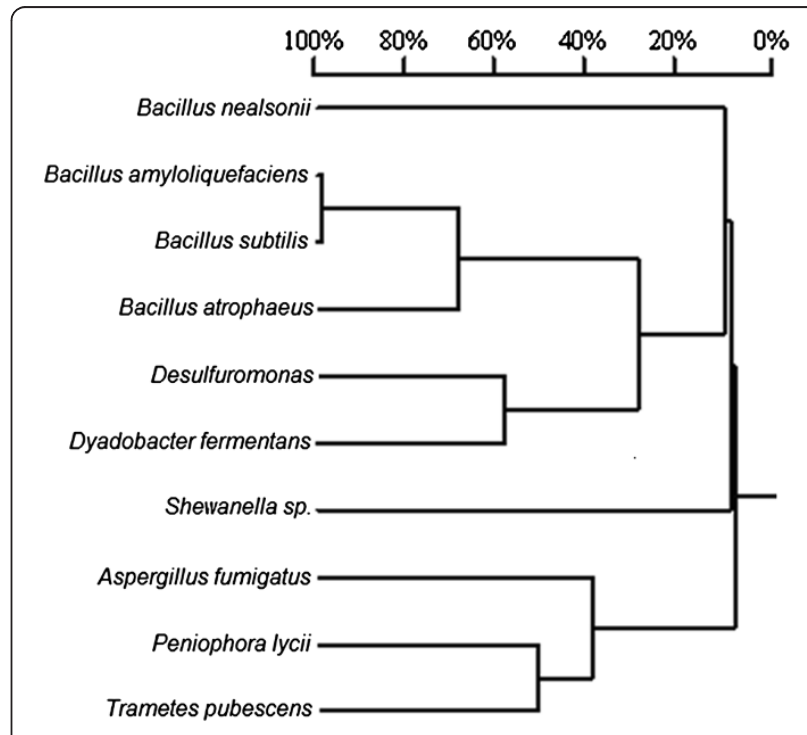

Figure 2 Polygenetic tree of phytases based on DNA sequences. 


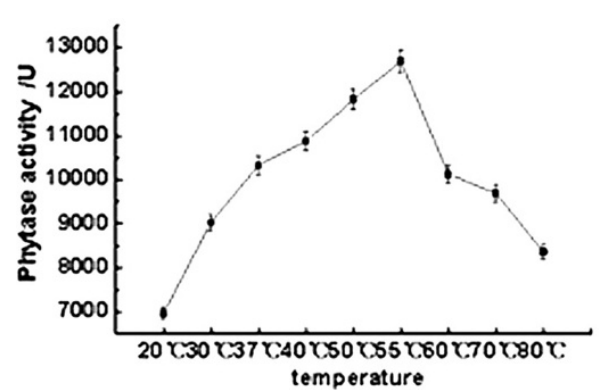

(a)

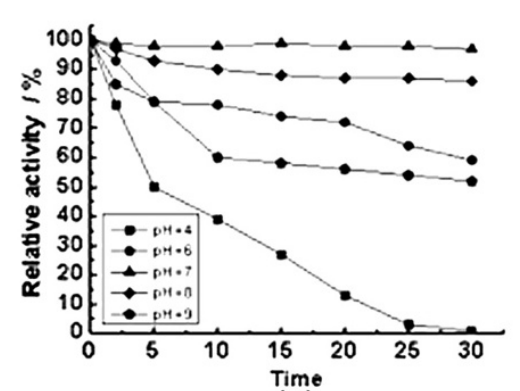

(c)

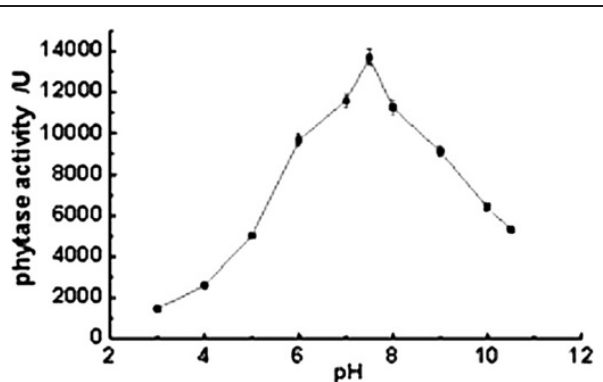

(b)

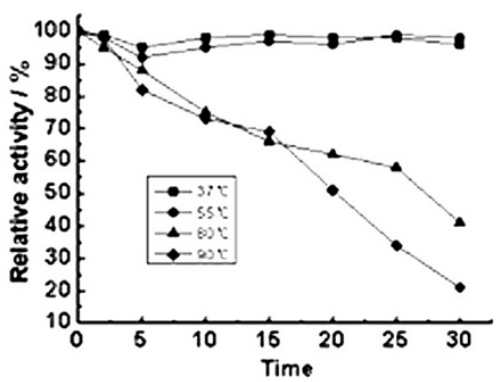

(d)

Figure 3 Enzymatic properties of the purified phytase. (a) Effect of temperature on the activity of the phytase. (b) Effect of pH on the activity of the phytase. (c) The thermal stability of the phytase. (d) pH stability of the phytase. The optimal temperatures for the activity of phytase were investigated by incubating $0.5 \mathrm{ml}$ reaction mixture for $10 \mathrm{~min}$. The reaction mixtures contained $0.2 \mathrm{ml}$ of $20 \mathrm{mM}$ phosphate buffer (pH 7.0), $0.2 \mathrm{ml}$ sodium phytate as the substrate and $0.1 \mathrm{ml}$ of the phytase, and the temperature range examined was $20-80^{\circ} \mathrm{C}$. The effect of pH on the activity of the phytase was studied using $0.5 \mathrm{ml}$ reaction mixtures containing $0.2 \mathrm{ml}$ of the buffer and $0.2 \mathrm{ml}$ sodium phytate as the substrate at $55^{\circ} \mathrm{C}$ for $10 \mathrm{~min}$. Buffers used were: $0.1 \mathrm{M}$ glycin - HCl buffer, $\mathrm{pH}$ 3.0; $0.1 \mathrm{M}$ acetic acid buffer, $\mathrm{pH} 4.0-5.0 ; 0.1 \mathrm{M}$ Tris-HCl buffer, $\mathrm{pH}$ 6.0 - 9.0; and 0.1 M glycine - NaOH buffer, pH 10.0 - 11.0. To study the stability of the phytase, aliquots of the enzyme solutions were subject to different temperatures and pHs for $30 \mathrm{~min}$. Temperatures used were $37,55,80$ and $90^{\circ} \mathrm{C}$. pHs used were 4, 6, 7, 8 and 9 . The residual activity of the phytase was detected once every $5 \mathrm{~min}$, and the relative activity of the phytase was calculated. The control sample is phytase at $4^{\circ} \mathrm{C}$ and $\mathrm{pH} 7.0$, and its activity is defined as $100 \%$.

Aspergillus oryzae $\left(60^{\circ} \mathrm{C}\right)$, Bacillus subtilis $\left(55-60^{\circ} \mathrm{C}\right)$, Escherichia coli $\left(55-60^{\circ} \mathrm{C}\right)$, Penicillium simplicissimum $\left(55^{\circ} \mathrm{C}\right)$, Aspergillus niger $\left(55-58^{\circ} \mathrm{C}\right)$ and Klebsiella terrigena $\left(58^{\circ} \mathrm{C}\right)$ [38-40]. Compared with acidic phytases from Saccharomyces cerevisiae (pH3.6), Cladosporium sp. FP-1 (pH4.0), Pichia anomala (pH4.0), Candida krusei (pH4.6), Lactobacillus sanfranciscensis (pH4.0), Pantoea agglomerans

Table 2 Effect of metal ions on the activity of the purified phytase

\begin{tabular}{lll}
\hline Metal ions $^{\mathbf{a}}$ & \multicolumn{2}{l}{ Relative activity (\%) } \\
\cline { 2 - 3 } & $\mathbf{1} \mathbf{~} \mathbf{M}$ & $\mathbf{5} \mathbf{~ m M}$ \\
\hline $\mathrm{Ba}^{2+}$ & 48 & 22 \\
$\mathrm{Ca}^{2+}$ & 104 & 99 \\
$\mathrm{Cu}^{2+}$ & 63 & 35 \\
$\mathrm{Co}^{2+}$ & 43 & 21 \\
$\mathrm{Mg}^{2+}$ & 97 & 62 \\
$\mathrm{Mn}^{2+}$ & 73 & 51 \\
$\mathrm{Ni}^{2+}$ & 40 & 20 \\
$\mathrm{Zn}^{2+}$ & 52 & 28 \\
\hline
\end{tabular}

${ }^{\mathrm{a}}$ The counter ion of these metal ions is $\mathrm{Cl}^{-}$.

${ }^{\mathrm{b}} \mathrm{Control}$ samples are phytase solutions without the addition of the metal ions.
(pH4.5), Klebsiella terrigena (pH5.0) and Penicillium simplicissimum (pH4.0) [40-42], the phytase from $B$. nealsonii ZJ0702 showed the optimal activity at $\mathrm{pH} 7.5$, indicating that it is neutral and should be suitable for the application in some aquaculture species whose digestive system $\mathrm{pH}$ is neutral. The thermal stability of the phytase suggests that it has stronger thermal stability than the phytase from Yersinia kristensenii [21]. The strong inhibition of the activity of the phytase by $\mathrm{Ba}^{2+}, \mathrm{Cu}^{2+}$ and $\mathrm{Co}^{2+}$ at $5 \mathrm{mM}$ shows that the active site of phytase may include $-\mathrm{SH}$ moieties. The high substrate specificity of the phytase for sodium phytate indicates that the phytase

Table 3 Substrate specificity of the purified phytase

\begin{tabular}{ll}
\hline Substrates & Relative activity (\%) \\
\hline Sodium phytate & 100 \\
pNPP & 0 \\
Glucose-1-phosphate & 0 \\
ATP & 0 \\
Fructose-1,6-diphosphate & 0 \\
B-Glycerophosphate & 0 \\
\hline
\end{tabular}


from B. nealsonii ZJ0702 is highly specific for inositol polyphosphate.

\section{Conclusions}

The results from this study demonstrate that the phytase from B. nealsonii ZJ0702 shows optimal activity at neutral $\mathrm{pH}$, strong thermal stability and high substrate specificity for sodium phytate. These unique properties make this phytase an attractive alternative to replace fungus-derived phytases for the hydrolysis of phytic acid and phytates. Extensive studies on the application of the purified phytase in food and feed processing are ongoing.

\section{Methods}

\section{Strain and reagents}

The strain B. nealsonii ZJ0702 was isolated from the soil at the Xihu district of Zhejiang Province, China, and was kept in our laboratory. This strain is deposited in the China General Microbiological Culture Collection (CGMCC, No.5396), and produces the extracellular phytase [43]. Phytic acid, sodium phytase, ATP, glucose-1phosphate, fructose-1, 6 -diphosphate, $\beta$-glycerophosphate and $p$-nitrophenylphosphate (pNPP), DEAE-sepharose and Sephadex G-100 were purchased from the Sigma Co., Ltd., LA, USA. PCR reagents and the PCR product purification kit were purchased from TaKaRa Biotech Co., Ltd., Japan. The UNIQ-10 DNA extraction kit was purchased from Sangon Co., Ltd., Shanghai, China. The strain culture medium contained $35 \mathrm{~g} / \mathrm{l}$ wheat bran, $20 \mathrm{~g} / \mathrm{l}$ tryptone, $5 \mathrm{~g} / \mathrm{l}$ $\mathrm{NH}_{4} \mathrm{NO}_{3}, 2 \mathrm{~g} / \mathrm{l} \mathrm{CaCl}, 0.5 \mathrm{~g} / \mathrm{l} \mathrm{KCl}, 0.5 \mathrm{~g} / \mathrm{l} \mathrm{MgSO}{ }_{4} \cdot 7 \mathrm{H}_{2} \mathrm{O}$

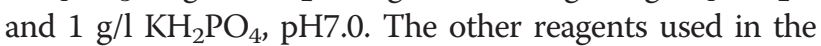
experiments were of analytical grade and used according to the specifications provided by the manufacturer.

\section{Strain culture}

A single colony of the strain B. nealsonii ZJ0702 was transferred from a slant culture to an Erlenmeyer flask $(1000 \mathrm{ml})$ containing $500 \mathrm{ml}$ of the culture medium, followed by incubation at $34^{\circ} \mathrm{C}$ with vigorous agitation in a shaking incubator at $165 \mathrm{rpm}$ for $72 \mathrm{~h}$ for producing the extracellular phytase.

\section{Enzyme purification}

All purification steps were carried out at $4^{\circ} \mathrm{C}$ unless otherwise stated. The $72 \mathrm{~h}$ culture broth was centrifuged at 12,000 rpm for $20 \mathrm{~min}$ to remove the cells. The supernatant was collected and ammonium sulfate was first added until 30\% saturation. The resultant precipitation was removed by centrifugation at 10,000 rpm for $30 \mathrm{~min}$ at $4^{\circ} \mathrm{C}$. Proteins were then fractioned from the supernatant by adding ammonium sulfate until different saturation levels were reached (40, 50, 60, 70 and 80\%). The obtained precipitates were pelleted by centrifugation at 10,000 rpm for $30 \mathrm{~min}$ at $4^{\circ} \mathrm{C}$, combined and resuspended in a $0.1 \mathrm{M}$ phosphate buffer (pH7.0). The combined precipitate was desalted using a dialysis bag (diameter: $0.45 \mu \mathrm{m}$ ) and then loaded onto a DEAE-sepharose Fast Flow ion-exchange column. Proteins were eluted at $0.8 \mathrm{ml} / \mathrm{min}$ using a phosphate buffer (pH7.0) containing a linear $\mathrm{NaCl}$-gradient with the concentration ranging between 0 and $2 \mathrm{M}$. The fractions with phytase activity were combined and concentrated by PEG 20,000. The concentrate was loaded onto a Sephadex G-100 chromatography column $(2.5 \times 35 \mathrm{~cm})$ pre-equilibrated with a phosphate buffer ( $\mathrm{pH} 7.0)$. Proteins were eluted at $0.5 \mathrm{ml} / \mathrm{min}$ using the same buffer. The fractions with phytase activity were collected and combined. The protein purity was determined by SDS-PAGE analysis. SDS-PAGE was carried out as described by Laemmli [44].

\section{Determination of the activity of phytase and the concentration of the total protein}

The phytase activity of samples collected from each purification step was analyzed. The phytase activity was determined as described by Engelen et al. [45] with minor modifications. Samples were diluted accordingly before the analysis. $0.5 \mathrm{ml}$ diluted samples and $25 \mathrm{mM}$ sodium phytate in $0.2 \mathrm{M}$ phosphate buffer ( $\mathrm{pH} 7.0$ ) were incubated separately at $55^{\circ} \mathrm{C}$ for $10 \mathrm{~min}$. Then, $0.5 \mathrm{ml}$ of the substrate was added to the sample and the mixture was incubated for another $10 \mathrm{~min}$. Thereafter, $2 \mathrm{ml}$ of $10 \mathrm{mM} \mathrm{NH}_{4} \mathrm{Mo}_{7} \mathrm{O}_{24} \cdot 4 \mathrm{H}_{2} \mathrm{O}: 5 \mathrm{~N} \mathrm{H}_{2} \mathrm{SO}_{4}$ :acetone (1:1:2) was added. The reaction was allowed to proceed for 30s. The reaction was halted by adding $0.1 \mathrm{ml}$ of $1 \mathrm{M}$ citric acid. The color of the reaction of the Pi (inorganic phosphate)Mo complex was read at $\mathrm{A}_{380}$. A reference standard $\left(\mathrm{KH}_{2} \mathrm{PO}_{4}, 0.1-0.4 \mu \mathrm{M}\right)$ was simultaneously assayed with the samples. A unit $(\mathrm{U})$ of phytase activity was defined as the amount of enzyme required to release $1 \mathrm{nM}$ of Pi per minute at $55^{\circ} \mathrm{C}$. The protein concentration was measured according to the Bradford method using bovine albumin as the standard [46].

\section{PCR amplification of the phytase gene and determination of the $\mathrm{N}$-terminal amino acid sequence}

The genomic DNA from B. nealsonii ZJ0702 was extracted using the UNIQ-10 DNA extraction kit according to the specifications provided by the manufacturer. The primer set, $\mathrm{P}_{1}$ : 5'-ATGGGAGCGATCGATACATGTCCAAAC-3' and $\mathrm{P}_{2}$ : 5' -TTAGATCGACCCCTGTATGACCACT-3', was designed for the amplification of the phytase gene by PCR with the genomic DNA as the template. PCR conditions consisted of an initial denaturation at $95^{\circ} \mathrm{C}$ for $5 \mathrm{~min}$, 35 cycles of the amplification consisted of denaturation at $95^{\circ} \mathrm{C}$ for $1 \mathrm{~min}$, annealing at $55^{\circ} \mathrm{C}$ for $1 \mathrm{~min}$ and extension at $72^{\circ} \mathrm{C}$ for $2 \mathrm{~min}$. Then a further extension at $72^{\circ} \mathrm{C}$ was performed for $10 \mathrm{~min}$. PCR products were purified by the PCR purification kit and sequenced by Sangon Co., Ltd., Shanghai, China. The homology analysis of phytases 
based on the DNA sequences was carried out with the DNAMAN 7.0 software. For the analysis of the N-terminal amino acid sequence of the purified phytase, the proteins on the SDS-PAGE gel were transferred to a PVDF membrane at $200 \mathrm{~V}$ for $1 \mathrm{~h}$. After the proteins were stained, the membrane corresponding to the protein band of the purified phytase was cut out and digested with sequencing grade trypsin, as described by Fernandez et al. [47], except that the detergent Triton X-100 was replaced by octyl- $\beta$-Dglucopyranoside (Boehringer Mannheim). Phytase was analyzed with a HP G1005A protein automated sequencing system (Hewlett- Packard Co., Ltd.).

\section{Enzymatic properties of the purified phytase}

The temperature stability of the phytase was determined by subjecting aliquots of phytase solutions to different temperatures for $30 \mathrm{~min}$. Temperatures used were 37 , 55,80 and $90^{\circ} \mathrm{C}$. The residual activity of the phytase was detected once every $5 \mathrm{~min}$. The effect of temperature on the activity of the phytase was determined at different temperatures ranging from 20 to $80^{\circ} \mathrm{C}$. Similarly, the optimal $\mathrm{pH}$ for the activity of the phytase was determined by mixing equal volumes of buffers at different $\mathrm{pH}$ values ranging from 3.0 to 11.0 at $55^{\circ} \mathrm{C}$, while the $\mathrm{pH}$ stability was examined by subjecting aliquots of phytase solutions to different $\mathrm{pH}$ values for $30 \mathrm{~min}$. The residual activity of the phytase was determined once for $5 \mathrm{~min}$. Buffers used were: $0.1 \mathrm{M}$ glycine- $\mathrm{HCl}$ buffer (pH3.0); $0.1 \mathrm{M}$ acetic acid buffer (pH4.0 - 5.0); 0.1 M Tris-HCl buffer (pH6.0 - 9.0); and $0.1 \mathrm{M}$ glycine-NaOH buffer (pH10.0-11.0). The phytase sample at $4{ }^{\circ} \mathrm{C}$ and $\mathrm{pH} 7.0$ was used as the control and its activity was defined as $100 \%$. The effect of metal ions on the activity of the phytase was studied by incubating metal ions with a purified enzyme solution $(0.5 \mathrm{ml})$ for $10 \mathrm{~min}$ at $55^{\circ} \mathrm{C}$. The following metal ions at 1 and $5 \mathrm{mM}$ were used: $\mathrm{Ba}^{2+}, \mathrm{Ca}^{2+}, \mathrm{Cu}^{2+}, \mathrm{Co}^{2+}, \mathrm{Mg}^{2+}, \mathrm{Mn}^{2+}$, $\mathrm{Ni}^{2+}$ and $\mathrm{Zn}^{2+}$. The substrate specificity of the purified enzyme was evaluated by following the standard assay procedure, except that the substrate was replaced with different phosphorylated compounds: pNPP, glucose-1-phosphate, ATP, fructose-1,6-diphosphate and $\beta$-glycerophosphate.

\section{Nucleotide sequence accession number}

The DNA sequence of the phytase from $B$. nealsonii ZJ0702 is in the GenBank database under accession number HQ843995.

\section{Competing interests}

Both authors declare that they have no competing interests.

\section{Authors' contributions}

PY designed and guided the experiments and wrote the manuscript. YC carried out the experiments. All authors read and approved the final manuscript.

\section{Acknowledgments}

The authors thank the Zhejiang Province Science and Technology Committee (No. 2011C22074) for generous support of this study.

Received: 25 February 2013 Accepted: 25 September 2013

Published: 28 September 2013

\section{References}

1. Lei $X G$, Porres JM: Phytase enzymology, applications, and biotechnology. Biotech Lett 2003, 25(21):1787-1794.

2. Wodzinski RJ, Ullah AHJ: Phytase. In Advances in Applied Microbiology. Edited by Saul LN, Allen IL. London Academic Press, Inc; 1996:263-302.

3. Columbus D, Niven SJ, Zhu CL, de Lange CFM: Phosphorus utilization in starter pigs fed high-moisture corn-based liquid diets steeped with phytase. J Anim Sci 2010, 88(12):3964-3976.

4. Cowieson AJ, Ravindran V, Selle PH: Influence of dietary phytic acid and source of microbial phytase on ileal endogenous amino acid flows in broiler chickens. Poultry Sci 2008, 87(11):2287-2299.

5. Dai F, Qiu L, Ye L, Wu D, Zhou M, Zhang G: Identification of a phytase gene in barley (Hordeum vulgare L.). PloS one 2011, 6(4):e18829.

6. Farhat A, Chouayekh H, Ben Farhat M, Bouchaala K, Bejar S: Gene cloning and characterization of a thermostable phytase from Bacillus subtilis US417 and assessment of its potential as a feed additive in comparison with a commercial enzyme. Mol Biotech 2008, 40(2):127-135.

7. Maga JA: Phytate: its chemistry, occurrence, food interactions, nutritional significance, and methods of analysis. J Agric Food Chem 1982, 30(1):1-9.

8. Harland BF, Morris ER: Phytate: A good or a bad food component? Nutr Res 1995, 15(5):733-754.

9. Graf E: Phytic acid: chemistry and applications. USA California: Pilatus Press; 1986.

10. Lee DY, Schroeder J, Gordon DT: Enhancement of Cu bioavailability in the rat by phytic acid. J Nutr 1988, 118(6):712-717.

11. Lei $X$, Stahl C: Biotechnological development of effective phytases for mineral nutrition and environmental protection. Appl Microb Biot 2001, 57(4):474-481.

12. Lei $\mathrm{X}, \mathrm{Ku}$ PK, Miller ER, Ullrey DE, Yokoyama MT: Supplemental microbial phytase improves bioavailability of dietary zinc to weanling pigs. J Nutr 1993, 123(6):1117-1123.

13. Lei XG, Ku PK, Miller ER, Yokoyama MT, Ullrey DE: Supplementing corn-soybean meal diets with microbial phytase maximizes phytate phosphorus utilization by weanling pigs. J Anim Sci 1993, 71(12):3368-3375.

14. Sebastian S, Touchburn SP, Chavez ER: Implications of phytic acid and supplemental microbial phytase in poultry nutrition: a review. World Poultry Sci J 1998, 54:27-47.

15. Harland BF, Oberleas D: Phytic acid complex in feed ingredients. In Phytase in Animal Nutrition and Waste Management: A BASF Reference. Mount Olive: NJ BASF Corp; 1999.

16. Yi Z, Kornegay ET, Ravindran V, Denbow DM: Improving phytate phosphorus availability in corn and soybean meal for broilers using microbial phytase and calculation of phosphorus equivalency values for phytase. Poultry Sci 1996, 75(2):240-249.

17. da Silva LG, Trugo LC, da Costa TS, Couri S: Low phytate lupin flour based biomass obtained by fermentation with a mutant of Aspergillus niger. Process Biochem 2005, 40(2):951-954.

18. Vohra A, Satyanarayana T: Phytase production by the yeast, Pichia anomala. Biotech Lett 2001, 23(7):551-554.

19. Vohra A, Rastogi SK, Satyanarayana T: Amelioration in growth and phosphorus assimilation of poultry birds using cell-bound phytase of Pichia Anomala. World J Microb Biotech 2006, 22(6):553-558.

20. Yoo GY, Wang XJ, Choi SY, Han K, Kang JC, Bai SC: Dietary microbial phytase increased the phosphorus digestibility in juvenile Korean rockfish Sebastes schlegeli fed diets containing soybean meal. Aquaculture 2005, 243(1-4):315-322.

21. Fu DW, Huang HQ, Luo HY, Wang YR, Yang PL, Meng K, Bai YG, Wu NF, Yao $\mathrm{B}$ : A highly $\mathrm{pH}$-stable phytase from Yersinia kristeensenii: Cloning, expression, and characterization. Enzyme Microb Tech 2008, 42(6):499-505.

22. In MJ, Jang ES, Kim YJ, Oh NS: Purification and properties of an extracellular acid phytase from Pseudomonas fragi Y9451. J Microb Biot 2004, 14:1004-1008.

23. Shah P, Bhavsar K, Soni S, Khire J: Strain improvement and up scaling of phytase production by Aspergillus niger NCIM 563 under submerged fermentation conditions. J Ind Microb Biot 2009, 36(3):373-380. 
24. Simon O, Igbasan F: In vitro properties of phytases from various microbial origins. Int J Food Sci Tech 2002, 37(7):813-822.

25. Shimizu M: Purification and characterization of phytase from Bacillus subtilis (natto) N-77. Biosci Biotech Biochem 1992, 56(8):1266-1269.

26. Nampoothiri K, Tomes G, Roopesh K, Szakacs G, Nagy V, Soccol CR, Pankey A: Thermostable phytase production by Thermoascus aurantiacus in submerged fermentation. Appl Biochem Biotech 2004, 118(1):205-214

27. Pandey A, Szakacs G, Soccol CR, Rodriguez-Leon JA, Soccol VT: Production, purification and properties of microbial phytases. Bioresour Technol 2001, 77(3):203-214

28. Bogar B, Szakacs G, Linden JC, Pandey A, Tengerdy RP: Optimization of phytase production by solid substrate fermentation. I Ind Microbiol Biot 2003, 30(3):183-189.

29. Chadha BS, Harmeet G, Mandeep M, Saini HS, Singh N: Phytase production by the thermophilic fungus Rhizomucor pusillus. World J Microb Biot 2004, 20(1):105-109.

30. Singh B, Kaur P, Satyanarayana T: Fungal phytases in ameliorating nutritional status of foods and combating environmental phosphorus pollution. In Microbes: Health and Environment. Edited by Chauhan AK, Verma A. New Delhi, India: IK International Publishers; 2006:289-326.

31. Lassen SF, Breinholt J, Østergaard PR, Brugger R, Bischoff A, Wyss M, Fuglsang CC: Expression, gene cloning, and characterization of five novel phytases from four Basidiomycete Fungi: Peniophora lycii, Agrocybe pediades, Ceriporia sp., and Trametes pubescens. Appl Environ Microb 2001, 67(10):4701-4707.

32. Maenz DD, Engele-Schaan CM, Newkirk RW, Classen HL: The effect of minerals and mineral chelators on the formation of phytase-resistant and phytase-susceptible forms of phytic acid in solution and in a slurry of canola meal. Anim Feed Sci Tech 1999, 81(3-4):177-192.

33. Oh BC, Choi WC, Park S, Kim YO, Oh TK: Biochemical properties and substrate specificities of alkaline and histidine acid phytases. Appl Microb Biotech 2004, 63(4):362-372.

34. Wyss M, Brugger R, Kronenberger A, Rémy R, Fimbel R, Oesterhelt G, Lehmann M, van Loon APGM: Biochemical characterization of fungal phytases (myo-inositol hexakisphosphate phosphohydrolases): catalytic properties. Appl Environ Microb 1999, 65(2):367-373.

35. Cao L, Wang WM, Yang CT, Yang Y, Diana J, Yakupitiyage A, Luo Z, Li DP: Application of microbial phytase in fish feed. Enzyme Microb Tech 2007, 40(4):497-507.

36. Kerovuo J, Lappalainen I, Reinikainen T: The metal dependence of Bacillus subtilis phytase. Biochem Biophy Res Comm 2000, 268(2):365-369.

37. Kim DH, Oh BC, Choi WC, Lee JK, Oh TK: Enzymatic evaluation of Bacillus amyloliquefaciens phytase as a feed additive. Biotech Lett 1999, 21(11):925-927.

38. Boyce A, Walsh G: Purification and characterisation of an acid phosphatase with phytase activity from Mucor hiemalis Wehmer. J Biotech 2007, 132(1):82-87.

39. Fujita J, Yamane YI, Fukuda H, Kizaki Y, Wakabayashi S, Shigeta S, Suzuki O, Ono K: Production and properties of phytase and acid phosphatase from a sake koji mold, Aspergillus oryzae. J Biosci Bioeng 2003, 95(4):348-353.

40. Greiner R, Konietzny U: Phytase for food application. Food Tech Biotech 2006, 44(2):125-140

41. Quan CS, Tian WJ, Fan SD, Kikuchi Jl: Purification and properties of a low- molecular-weight phytase from Cladosporium sp. FP-1. J Biosci Bioeng 2004, 97(4):260-266

42. In MJ, Seo SW, Kim DC, Oh NS: Purification and biochemical properties of an extracellular acid phytase produced by the Saccharomyces cerevisiae CY strain. Process Biochem 2009, 44(1):122-126.

43. Yu P, Chen YR: Screening and identification of novel phytase-producing Bacillus strain from soil. J Chin Inst Food Sci Tech 2010, 10:116-121.

44. Laemmli UK: Cleavage of structural proteins during the assembly of the head of bacteriophage T4. Nature 1970, 227:680-685.

45. Engelen AJ, Vander HFC, Randsdorp PHG, Smit EL: Simple and rapid determination of phytase activity. J AOAC Int 1994, 77:760-764.
46. Bradford MM: A rapid and sensitive method for the quantization of microgram quantities of protein utilizing the principle of protein-dye binding. Anal Biochem 1976, 72:248-254.

47. Fernandez J, DeMott M, Atherton D, Mische SM: Internal protein sequence analysis: enzymatic digestion for less than 10 micrograms of protein bound to polyvinylidene difluoride or nitrocellulose membranes. Anal Biochem 1992, 201(2):255-264.

doi:10.1186/1472-6750-13-78

Cite this article as: $Y u$ and Chen: Purification and characterization of a novel neutral and heat-tolerant phytase from a newly isolated strain Bacillus nealsonii ZJ0702. BMC Biotechnology 2013 13:78.

\section{Submit your next manuscript to BioMed Central and take full advantage of:}

- Convenient online submission

- Thorough peer review

- No space constraints or color figure charges

- Immediate publication on acceptance

- Inclusion in PubMed, CAS, Scopus and Google Scholar

- Research which is freely available for redistribution

Submit your manuscript at www.biomedcentral.com/submit
C Biomed Central 